\title{
The Effect of Diazinon on Blood Plasma Biochemistry in Carp (Cyprinus carpio L.)
}

\author{
V. LUSKOVÁ ${ }^{1}$, M. SVOBODA ${ }^{2}$, J. KOLÁŘOVÁ 3 \\ ${ }^{1}$ Institute of Vertebrate Biology, AS CR, Brno, Czech Republic \\ ${ }^{2}$ University of Veterinary and Pharmaceutical Sciences, Brno, Czech Republic \\ ${ }^{3}$ University of South Bohemia, Research Institute of Fish Culture and Hydrobiology, \\ Vodňany, Czech Republic \\ Received May 16, 2001 \\ Accepted October 31, 2001
}

\section{Abstract}

Lusková V., M. Svoboda, J. Kolářová: The Effect of Diazinon on Blood Plasma Biochemistry in Carp (Cyprinus carpio L.). Acta Vet. Brno 2002, 71: 117-123.

The aim of this study was to evaluate the effect of diazinon [0,0-diethyl-0-(2-isopropyl-6methylpyrimidin-4yl) phosphorothioate] on common carp (Cyprinus carpio L.). The effect was assessed by comparing the biochemical blood plasma profiles of a control group and a group exposed to the effect of the pesticide Basudin $600 \mathrm{EW}$ (containing $600 \mathrm{~g} . \mathrm{l}^{-1}$ diazinon as the toxic substance). The activities of selected enzymes, metabolite concentrations and electrolytes were measured in 15 specimens of controls, $\mathrm{K}_{1-}$ and in 16 specimens, $\mathrm{K}_{1-2}$, exposed for $96 \mathrm{~h}$ to the effects of Basudin $600 \mathrm{EW}$ at a concentration of 32.5 mg. $1^{-1}$. Compared with the control group, a significant decrease of cholinesterase $(p<0.01)$ and lactate dehydrogenase $(p<0.05)$ was ascertained in the experimental group. The values of alanine and aspartate aminotransferases, creatine kinase, alkaline and acide phosphatases were comparable in the experimental and control groups. The total protein and lactate concentration were significantly lower $(p$ $<0.05)$ in the experimental group, compared with the control group. On the contrary, glucose concentration in the plasma of the experimental group was significantly higher $(p<0.01)$ than in that of the control group. The experimental group showed a significantly higher $(p<0.05)$ concentration of plasmatic natrium and potassium, and a significantly lower $(p<0.05)$ concentration of plasmatic calcium and phosphorus, compared with those in the control group. The above results of examinations of the biochemical blood plasma profile indicate a marked neurotoxic effect of diazinon in fishes.

Organophosphorous pesticide, acute toxicity, enzymes, total protein, glucose, lactate, electrolytes

Diazinon is a widely used toxicant in a number of organophosphorous pesticides (Roberts and Hutson 1998). Although the aquatic environment is not the target one for the use of such pesticides the results of a number of monitoring studies have evidenced the presence of diazinon and its metabolite, diazoxon, in surface waters (Mansingh and Wils on 1996; Tsuda et al. 1996; Van der Geest et al. 1997; Bailey et al. 2000; de Vlaming et al. 2000). That is why great attention has been paid to the effect of diazinon on fish organism. Biochemical characteristics of blood are among the important indices of the status of internal environment of the fish organism (Edsall 1999). Changes in the biochemical blood profile mirror changes in metabolism and biochemical processes of the organism, resulting from the effects of various pollutants, and they make it possible to study the mechanisms of the effects of these substances.

The major biochemical response to the effect of diazinon in fishes is the inhibition of a number of enzymes, above all acetylcholinesterase (Goodman et al. 1979; Sastry and Sharma 1980; Ansari et al. 1987; Hamm et al. 1998). Also observed have been changes in carbohydrate metabolism in the eel, Anguilla anguilla, during short-term exposure to diazinon (Ceron et al. 1997). The glycogen contents in the liver and muscular tissue was significantly decreased, glucose and lactate concentrations in the blood were significantly increased. Ans ari and Kumar (1988) observed a significantly decreased content of DNA, RNA and liver proteins following a short-term action of diazinon on Zebra Danio, Brachydanio rerio.

Address for correspondence:

RNDr. Věra Lusková, PhD.

Institute of Vertebrate Biology AS CR

Květná 8, 60365 Brno, Czech Republic
Phone: +420543422527

Fax: +4205 43211346

http://www.vfu.cz/acta-vet/actavet.htm 
The present paper is a sequel to an earlier contribution devoted to the effect of diazinon on the haematological indices in common carp ( $\mathrm{S}$ v obo da et al. 2001). Here we present the results of our assessment of the effect of diazinon on the biochemical blood plasma profile in common carp.

\section{Materials and Methods}

The blood plasma of carp (Cyprinus carpio $\mathrm{L}$.) one till two years aged $\left(\mathrm{K}_{1-2}\right)$ was examined at the end of a 96 hour test of acute toxicity of Basudin $600 \mathrm{EW}$ at a concentration of $32.5 \mathrm{mg} . \mathrm{l}^{-1}$, an organophosphorous pesticide containing $600 \mathrm{~g} . \mathrm{l}^{-1}$ diazinon substances as a toxicant. The Basudin $600 \mathrm{EW}$ concentration used is the $\mathrm{LC}_{50}$ of this substance for carp of that age category. At the same time, a biochemical examination involved a control group of carp that was a part of the test. The test was carried out in a semistatic way, the bath being exchanged every $24 \mathrm{~h}$. The basic physical and chemical indices of diluting water used in this acute toxicity test were as follows: $\mathrm{pH} 7.82$ $\mathrm{ANC}_{4.5}$ (alkalinity) $1.05 \mathrm{mmol} \cdot \mathrm{l}^{-1} ; \mathrm{BNC}_{8.3}$ (acidity) $0.03 \mathrm{mmol} \cdot \mathrm{l}^{-1} ; \mathrm{COD}_{\mathrm{Mn}} 1.0 \mathrm{mg} \cdot \mathrm{l}^{-1} ; \mathrm{NH}_{4}^{+}+\mathrm{NH}_{3} 0.1 \mathrm{mg} \cdot \mathrm{l}^{-1}$; $\mathrm{NO}_{3}{ }^{-1} 11.56 \mathrm{mg} \cdot \mathrm{l}^{-1} ; \mathrm{NO}_{2}^{-} 0.015 \mathrm{mg} \cdot \mathrm{l}^{-1} ; \mathrm{PO}_{4}^{3-} 0.01 \mathrm{mg} \cdot \mathrm{l}^{-1}$; sum of $\mathrm{Ca}+\mathrm{Mg} 14 \mathrm{mg} \cdot \mathrm{l}^{-1}$. During the test the water temperature varied between 20.8 and $21.5^{\circ} \mathrm{C}$, water saturation with oxygen ranged from 90 to $100 \%$, pH from 7.60 to 7.85 . The test was carried out in five aquariums 2001 in volume each, and each containing $10 \mathrm{~K}_{1-2}$ ( 2 controls, 3 aquariums containing Basudin $600 \mathrm{EW}$ at a concentration of $32.5 \mathrm{ml} \cdot \mathrm{l}^{-1}$ ).

Biochemical analyses of blood plasma involved 15 specimens of control $\mathrm{K}_{1-2}(254 \pm 48.6 \mathrm{~g}$ in weight $)$ and 16 experimental ones $(268 \pm 46.7 \mathrm{~g}$ in weight $)$.

Blood was sampled by cardiac puncture. Heparin in amount of $50 \mathrm{IU}$ sodium salt per $1 \mathrm{ml}$ blood was used for stabilisation. After sampling the blood was centrifuged for $15 \mathrm{~min}$ at $400 \mathrm{~g}$. The activity of alanine aminotransferase (ALT), aspartate aminotransferase (AST), cholinesterase (CHE) with substrate butyrylthiocholine, lactate dehydrogenase (LDH), creatine kinase (CK), alkaline phosphatase (ALP), acid phosphatase (ACP) and total protein (TP), glucose (GLU), lactate (LACT) and electrolyte ( $\mathrm{Na}, \mathrm{K}, \mathrm{Ca}, \mathrm{P}$ ) concentrations were determined using the automatic analyser COBAS MIRA (Hoffmann, La Roche, Co. Switzerland) and using optimised tests of Boehringer Mannheim GmBH by means of spectrophotometer Varian DMS 200. For the determination of CK activities the plasma was diluted 5-10 times with a physiological solution. One-way ANOVA was used to compare the values of biochemical indices in the blood plasma of the control and experimental fish.

\section{Results}

The following clinical symptoms were recorded during blood sampling in the experimental carp group after $96 \mathrm{~h}$ of action of the diazinon-based organophosphorous pesticide Basudin EW 600 at a concentration of $32.5 \mathrm{mg} \cdot \mathrm{l}^{-1}$ : loss of movement co-ordination and orientation in water the fish were swimming in a half-circle, continuously lying on one side; their response to external stimuli was a bouncing movement and fin tremor; there was a conspicuous darkening of the body surface, particularly in its dorsal part. During blood sampling, the control carp showed no clinical changes.

Fig. 1 shows a comparison of enzyme CHE and LDH activities in control carp and those exposed to acute action of diazinon. Diazinon caused a significant decrease $(p<0.01)$ in
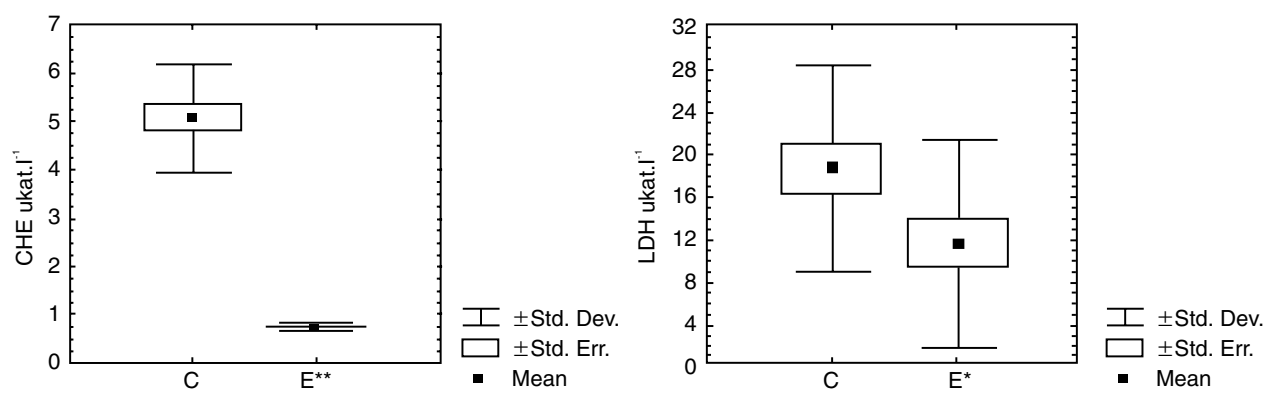

C - control group; E - experimental group Significance: ${ }^{\star} p<0.05 ;{ }^{* \star} p<0.01$

Fig. 1. The effect of diazinon on activites of CHE and LDH in the blood plasma of carp. 
CHE activity in the experimental carp, compared with the control ones. Essentially, the enzyme activity dropped by one order of magnitude. A less marked yet also significant decrease $(p<0.01)$ was observed in the LDH activity in the experimental group, compared with the control one. The activity of the other enzymes under study (AST, ALT, CK, ALP, $\mathrm{ACP}$ ) in the control and experimental carp are given in Table 1. They are comparable, showing no significant differences between the two groups. From the ALP activities in the experimental group, three times higher values were excluded as a mean. In the case of ACP, two values were excluded that dropped bellow zero.

Table 1

The effect of diazinon on enzyme activities in blood plasma of carp

\begin{tabular}{|c|c|c|c|c|c|c|c|}
\hline Enzymes & Units & Groups & $\mathrm{N}$ & Means & SD & Variance & Probability \\
\hline AST & $\mu \mathrm{kat} \cdot \mathrm{l}^{-1}$ & $\begin{array}{c}\text { control } \\
\text { experiment }\end{array}$ & $\begin{array}{l}15 \\
16\end{array}$ & $\begin{array}{l}6.84 \\
6.01\end{array}$ & $\begin{array}{l}1.94 \\
2.84\end{array}$ & $\begin{array}{l}3.75 \\
8.06\end{array}$ & 0.35 \\
\hline ALT & $\mu \mathrm{kat} \cdot \mathrm{l}^{-1}$ & $\begin{array}{c}\text { control } \\
\text { experiment }\end{array}$ & $\begin{array}{l}15 \\
16\end{array}$ & $\begin{array}{l}1.58 \\
1.78\end{array}$ & $\begin{array}{l}0.59 \\
1.01\end{array}$ & $\begin{array}{l}0.35 \\
1.02\end{array}$ & 0.52 \\
\hline CK & $\mu \mathrm{kat} \cdot \mathrm{1}^{-1}$ & $\begin{array}{c}\text { control } \\
\text { experiment }\end{array}$ & $\begin{array}{l}15 \\
16\end{array}$ & $\begin{array}{l}639.05 \\
613.91\end{array}$ & $\begin{array}{l}208.95 \\
297.23\end{array}$ & $\begin{array}{l}43658.62 \\
88344.32\end{array}$ & 0.79 \\
\hline ALP & $\mu \mathrm{kat} \cdot \cdot^{-1}$ & $\begin{array}{c}\text { control } \\
\text { experiment }\end{array}$ & $\begin{array}{l}15 \\
15\end{array}$ & $\begin{array}{l}0.73 \\
0.72\end{array}$ & $\begin{array}{l}0.16 \\
0.22\end{array}$ & $\begin{array}{l}0.02 \\
0.05\end{array}$ & 0.89 \\
\hline $\mathrm{ACP}$ & $\mu \mathrm{kat} \cdot \mathrm{l}^{-1}$ & $\begin{array}{c}\text { control } \\
\text { experiment }\end{array}$ & $\begin{array}{l}13 \\
15\end{array}$ & $\begin{array}{l}0.09 \\
0.06\end{array}$ & $\begin{array}{l}0.04 \\
0.04\end{array}$ & $\begin{array}{l}0.00 \\
0.00\end{array}$ & 0.18 \\
\hline
\end{tabular}
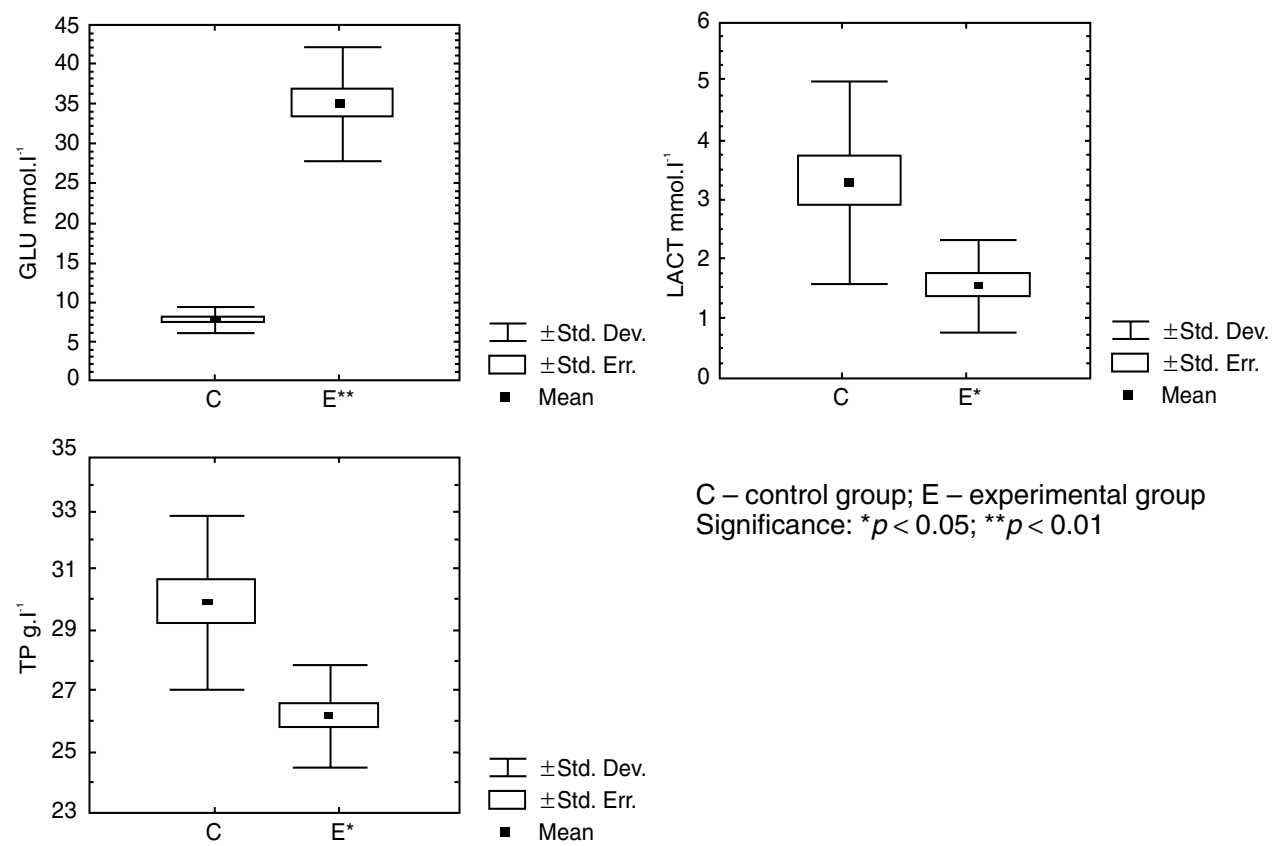

C - control group; $\mathrm{E}-$ experimental group Significance: ${ }^{\star} p<0.05 ;{ }^{\star \star} p<0.01$

Fig. 2. The effect of diazinon on glucose, lactate and total protein concentraction in blood plasma of carp. 

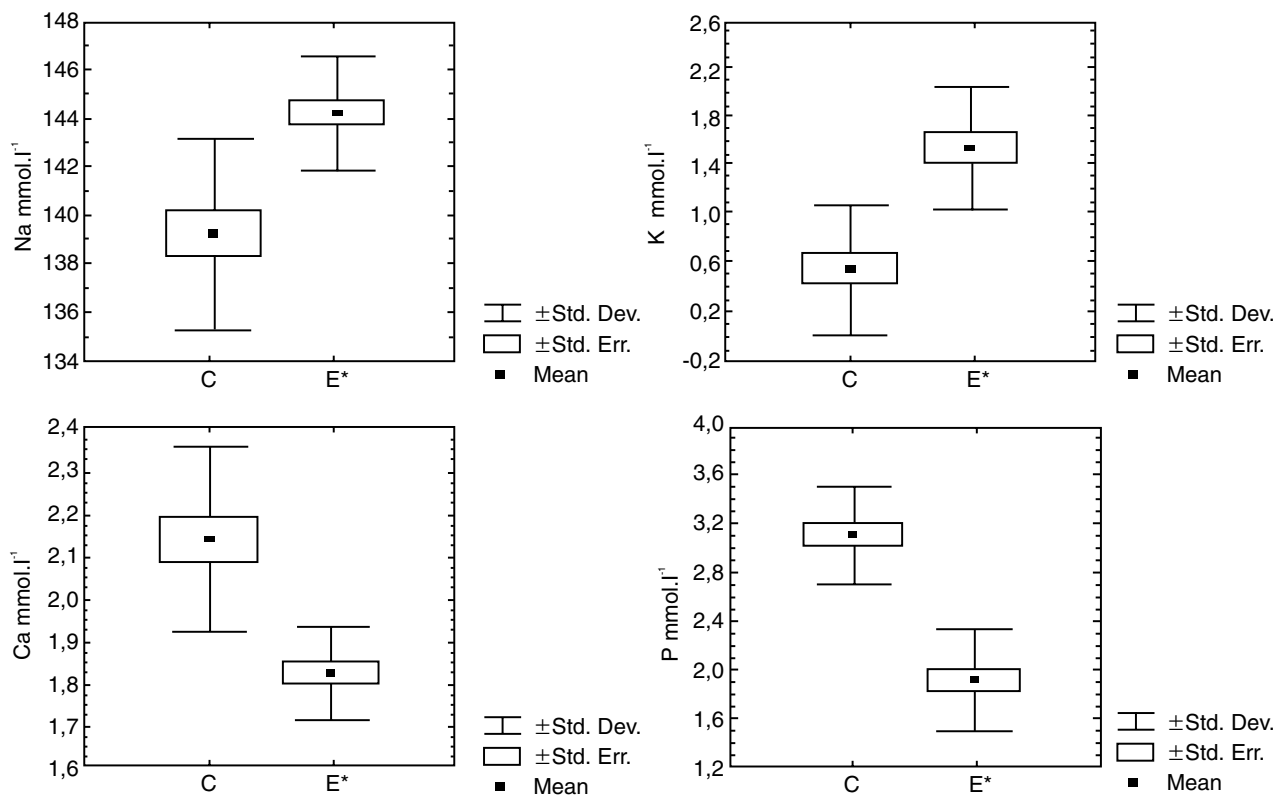

$\mathrm{C}$ - control group; $\mathrm{E}$ - experimental group Significance: ${ }^{*} p<0.05 ;{ }^{* \star} p<0.01$

Fig. 3. The effect of diazinon on electrolyte concentration in blood plasma of carp.

Fig. 2 shows the concentrations of TP, GLU and LACT in the blood plasma of the control and experimental groups of carp. The group affected by an acute effect of diazinon exhibited significantly lower $(\mathrm{p}<0.05)$ TP and LACT concentrations, compared with the control fish. On the other hand, GLU concentration was significantly higher $(p<0.01)$ in the experimental group, compared with that in the control group.

The concentration of electrolytes under study ( $\mathrm{Na}, \mathrm{K}, \mathrm{Ca}, \mathrm{P})$ in the blood plasma of the control and experimental groups of carp are compared in Fig. 3. In the experimental group, the acute effect of diazinon caused significantly higher $(p<0.05)$ concentrations of sodium and potassium, and significantly lower concentrations $(p<0.05)$ of calcium and phosphorus, compared with the control group.

\section{Discussion}

The acute effect of diazinon (in form of the pesticide Basudin $600 \mathrm{EW}$ at a concentration of $32.5 \mathrm{mg} \cdot \mathrm{l}^{-1}$ ) on carp caused in cholinesterase with substrate butyrylthiocholine the activity drop by $85 \%$, compared with that in the control group $(p<0.01)$. This result agrees with data on the $71 \%$ inhibition of acetylcholinesterase in the brain of Cyprinodon variegatus (Goodman et al. 1979) and on the $80 \%$ inhibition of that enzyme in the neural tissue of Brachydanio rerio following an acute effect of diazinon (An sari et al. 1987). Diazinon alone is no inhibitor of cholinesterase. However, in animal bodies it is converted to diazoxon, which is a strong inhibitor of that enzyme (Eisler 1986, Gallo and Lawryk 1991). Inactivation of CHE causes a blockage of the cholinergic transfer of nerve signals, paralysis and death due to asphyxia (Voet and Voetová 1990). 
Sastry and Sharma (1980) report decreased lactate dehydrogenase activity in the brain of Channa punctata following an action of diazinon lasting $96 \mathrm{~h}$. According to our results, the assumed decrease in lactate dehydrogenase activity in the brain was mirrored even in the significantly decreased activity of this enzyme in the blood plasma of our carp exposed to diazinon $(p<0.05)$. On the other hand, the activities alkaline and acid phosphatases in blood plasma were almost identical in the control and experimental groups of carp. Sastry and Sharma (1980) report decrease of activities in alkaline and acid phosphatases in the brain of Channa punctata following the effect of diazinon. According to these authors, the alkaline phosphatase activity is inhibited after $96 \mathrm{~h}$ of the effect and then it resumes its normal values or even an increased activity is observed. Goel et al. (1982) report serum alkaline and acid phosphatases decreased by $15 \%$ in Heteropneustes fossilis, resulting from the effect of the organophosphate malathion. The resulting activity values of alkaline and acid phosphatases support the assumption that the liver tissue of the experimental fish was not markedly affected.

Likewise, the practically identical activity of alanine and aspartate aminotransferases and creatine kinase, observed in the control and experimental carp groups, indicate that diazinon damages neither parenchymatous tissues nor skeletal musculature. Nor does it disturb the permeability and integrity of cell membranes (Masopust 1998).

The significant differences between the control and experimental groups of carp following the action of diazinon, measured especially in glucose concentration $(p<0.01)$ or even lactate concentration $(p<0.05)$, may be considered to be the manifestation of stress. In agreement with our results, Ceron et al. (1997) report significant glucose increase in common eel (Anguilla anguilla) following a $96 \mathrm{~h}$ action of sublethal concentrations of diazinon. Glucose increase is a general response of fish to acute pollutant effects, including organophosphates (Svobodová 1971; Srivastava 1981; Singh and Srivastava 1982; Mishra and Srivastava 1983; Natarajan 1989; Gill et al. 1990; Balint et al. 1995; Sancho et al. 1997).

The significant drop $(p<0.05)$, by approximately $50 \%$, in the lactate concentration and lactate dehydrogenase activity in the blood plasma of the experimental fish, compared with the control group, indicates a decrease in the glycolytic process due to the lower metabolic rate as a result of the effect of diazinon. On the contrary, most authors report increased plasma lactate concentration in various fishes following acute effects of organophosphorous pesticides including diazinon (Ceron et al. 1997; Sancho et al. 1997; Gille et al. 1990; Singh and Srivastava 1982; Natarajan 1989). However, Srivastava (1981) reportsan increase of plasma lactate concentration after $3 \mathrm{~h}$ of action by methylparathion and, on the contrary, significant decrease of plasma lactate concentration in time periods of 48 and $96 \mathrm{~h}$.

After $96 \mathrm{~h}$ of action, diazinon produced a significant decrease $(p<0.05)$ in protein concentration in the blood plasma of the experimental carp, as compared with the control ones. In agreement with our data, a significant decrease protein concentration following an acute effect of fenitrothion has been reported by Sancho et al. (1997) in the eel and by Khattak and Hafeez (1996) in Cyprinion watsoni exposed to the effect of malathion.

The basic function of electrolytes in the body lies in controlling fluid distribution, intraand extracellular acidobasic equilibrium, maintaining osmotic pressure of body fluids and normal neuro-muscular irritability (Harper 1977). The increase in the concentration of natrium ions found in the blood plasma of the experimental carp was a mere $4 \%$, showing no practical effect on the ion functions mentioned above. On the other hand, the kalium ion concentration in the plasma were increased three times, which in combination with the decrease in cholinesterase indicates inhibition of the heart function and a neurotoxic damage to the CNS of the experimental fish. Also, the calcium and phosphorus ions functionally 
participate in maintaining normal irritability of the heart, muscles and nerves, as well as the selective permeability of cell membranes. Therefore, the significant decrease $(p<0.05)$ in the concentrations of the above ions in the experimental fish fits in the diagnosis caused by the toxic effect of the pesticide tested. The overall picture of changes in the composition of ion concentrations does not exclude possible kidney damage in the experimental fish group. This question, however, requires examinations of additional supporting diagnostic indices. The decrease of concentration in phosphorus ions and in plasma lactate, and decrease of lactate dehydrogenase activity, as of products and activator of glucose metabolism, indicated the decrease of this process intensity in the experimental group due to toxic effects of diazinon. This hypothesis is also supported by the glucose concentration increase, as compared with the control group. Symptoms of locomotor irritation in the fish experimental group were not manifested by increase in the mean value of creatine kinase activity as compared with that in the control group.

\section{Vliv diazinonu na biochemický profil krevní plasmy kapra obecného (Cyprinus carpio L.)}

Cílem práce bylo zhodnotit vliv diazinonu [0,0-diethyl-0-(2- isopropyl-6-methylpyrimidin-4yl) phosphorothioate] na kapra obecného (Cyprinus carpio L.). Účinek byl posuzován porovnáním biochemického profilu krevní plasmy kontrolní a pokusné skupiny vystavené působení pesticidního přípravku Basudin $600 \mathrm{EW}$ (účinná látka $600 \mathrm{~g} \cdot \mathrm{l}^{-1}$ diazinonu). Měření aktivit vybraných enzymů, koncentrací metabolitů a elektrolytů bylo provedeno u 15 kontrolních $\mathrm{K}_{1-2}$ a u 16 pokusných $\mathrm{K}_{1-2}$ po 96 hodinovém působení Basudinu $600 \mathrm{EW} \mathrm{v}$ koncentraci $32,5 \mathrm{mg} \cdot \mathrm{l}^{-1}$. U pokusné skupiny kaprů bylo zjištěno signifikantní snížení aktivity CHE $(p<0,01)$ a LDH $(p<0,05)$ ve srovnání s kontrolní skupinou. Hodnoty aktivit ALT, AST, CK, ALP a ACP byly u pokusné a kontrolní skupiny srovnatelné. Koncentrace celkových bílkovin a laktátu byly u pokusné skupiny signifikantně nižší $(p<0,05)$ ve srovnání s kontrolními rybami. Naproti tomu koncentrace glukosy v plasmě pokusných kaprů byla signifikantně vyšší $(p<0,01)$ oproti kontrolní skupině. U pokusné skupiny byla zjištěna signifikantně vyšší koncentrace plasmatického sodíku a draslíku $(p<0,05)$ a signifikantně nižší koncentrace plasmatického vápníku a fosforu $(p<0,05)$ ve srovnání s kontrolní skupinou. Výsledky provedeného vyšetření biochemického profilu krevní plasmy zkoumaných kaprů svědčí o výrazném neurotoxickém působení diazinonu u ryb.

\footnotetext{
Acknowledgement

This research was supported by grant from the Czech Ministry of Education (MSM 126100003).
}

\section{References}

ANSARI, B.A., ASLAM, M., KUMAR, K. 1987: Diazinon toxicity: activities of acetylcholinesterase and phosphatases in the nervous tissue of Zebra Danio, Brachydanio rerio (Cyprinidae). Acta Hydrochim. Hydrobiol. 15: 301-306

ANSARI, B. A., KUMAR, K. 1988: Diazinon toxicity: effect on protein and nucleic acid metabolism in the liver of zebrafish, Brachydanio rerio (Cyprinidae). Sci. Total Environ. 76: 63-68

BAILEY, H. C., DEANOVIC, L., REYES, E., KIMBALL, T., LARSON, K., CORTRIGHT, K., CONNOR, V., HINTON, D. E. 2000: Diazinon and chlorpyrifos in urban waterways in northern California, USA. Environ. Toxicol. Chem. 19: 82-87

BALINT, T., SZEGLETES, T., SZEGLETES, Z., HALASY, K., NEMCSOK, J. 1995: Biochemical and subcellular changes in carp exposed to the organophosphorous methidathion and the pyrethroid deltamethrin. Aquat. Toxicol. 33: 279-295

CERON, J.J., SANCHO, E., FERRANDO, M.D., GUTIERREZ, C., ANDREU, E. 1997: Changes in carbohydrate metabolism in the eel Anguilla anguilla, during short-term exposure to diazinon. Toxicol. Environ. Chem. 60: 201-210 
DE VLAMING, V., CONNOR, V., DIGIORGIO, C., BAILEY, H. C., DEANOVIC, L. A., HINTON, D. E. 2000: Application of whole effluent toxicity test procedures to ambient water quality assessment. Environ. Toxicol. Chem. 19: 42-62

EDSALL, C. C. 1999: A blood chemistry profile for lake trout. J. Aq. Animal Health 11: 81-86

EISLER, R. 1986: Diazinon hazards to fish, wildlife, and invertebrates: A synoptic review. U. S. Fish Wildl. Serv. Biol. Rep. 85: 37 pp.

GALLO, M. A., LAWRYK, N. J. 1991: Organic phosphorus pesticides. Academic Press, New York, 5-3, Ex. The extension toxicology network. PIPs. Extoxnet ace.orst.edu

GILL, T.S., PANDE, J., TEWARI, H. 1990: Sublethal effects of an organophosphorus insecticide on certain metabolite levels in a freshwater fish, Puntius conchonius Hamilton. Pestic. Biochem. Physiol. 36: 290-299

GOEL, K. A., TYAGI, S. K., AWASTHI, A. K. 1982: Effect of malathion on some haematological values in Heteropneustes fossilis. Comp. Physiol. Ecol. 7: 259-261

GOODMAN, L. R., HANSEN, D. J., COPPAGE, D. L., MOORE, J. C., MATTHEWS, E. 1979: Diazinon: chronic toxicity and brain acetylcholinesterase inhibition in the sheepshead minnow, Cyprinodon variegatus. Trans. Am. Fish. Soc. 108:479-488

HAMM, J. T., WILSON, B. W., HINTON, D. E. 1998: Organophosphate-induced acetylcholinesterase inhibition and embryonic retinal cell necrosis in vivo in the teleost (Oryzias latipes). Neurotoxicology 19: 853-870

HARPER, H. A. 1977: Přehled fysiologické chemie. Avicenum, Praha 1977, pp. 639

KHATTAK, I. U. D., HAFEEZ, M. A. 1996: Effect of malathion on blood parameters of the fish, Cyprinion watsoni. Pak. J. Zool. 28: 45-49

MANSINGH, A., WILSON, A. 1995: Insecticide contamination of Jamaican environment 3. Baseline studies on the status of insectidical pollution of Kingston Harbour. Mar. Pollut. Bull. 30: 640-645

MASOPUST, J. 1998: Klinická biochemie. Požadování a hodnocení biochemických vyšetř̌ení. I. část. Karolinum Praha, $429 \mathrm{p}$.

MISHRA, J., SRIVASTAVA, A. K. 1983: Malathion induced hematological and biochemical changes in the Indian catfish Heteropneutes fossilis. Environ. Res. 30: 393-398

NATARAJAN, G. M. 1989: Changes in the carbohydrate metabolites during acute and chronic exposure of airbreathing fish Channa striatus to oxydemeton methyl (metasystox). Comp. Physiol. Ecol. 14: 181-184

ROBERTS, T. R., HUTSON, D. H. 1998: Metabolits pathways of agrochemicals. Part 2: Insecticides and fungicides. The Royal Soc. Chem. Cambridge, $1475 \mathrm{p}$.

SANCHO, E., FERRANDO, M. D., ANDREV, E. 1997: Sublethal effects of an organophosphate insectidide on the European eel, Anguilla anguilla. Ecotoxicol. Environ. Saf. 36: 57-65

SASTRY, K. V., SHARMA, K. 1980: Diazinon effect on the activities of brain enzymes from Opiocephalus punctatus (Channa). Bull. Environ. Contam. Toxicol. 24: 326-332

SINGH, H. H., SRIVASTAVA, A. K. 1982: Effect of formothion on carbohydrate metabolism in Indian catfish (Heteropneustes fossilis). Environ. Res. 28: 335-339

SRIVASTAVA, A. K. 1981: Effects of acute exposure of methyl parathion on carbohydrate metabolism of Indian catfish (Heteropneustes fossilis). Acta Pharmacol. Toxicol. 48: 26-34

SVOBODA M., LUSKOVÁ V., DRASTICHOVÁ J., ŽLÁBEK, V. 2001: The effect of diazinon on haematological indices of common carp (Cyprinus carpio L.). Acta Vet. Brno 70: 457-465

SVOBODOVÁ, Z. 1971: Some haematological and metabolic changes in fish occurring after pesticide intoxication. Buletin VÚR Vodňany 7: 29-36

TSUDA, T., INOUE, T., KOJIMA, M., AOKI, S. 1996: Pesticides in water and fish from rivers flowing into lake Biwa. Bull. Environ. Contam. Toxicol. 57: 442-449

VAN DER GEEST, H. G., STUIJFZAND, S. C., KRAAK, M. H. S., ADMIRAAL, W. 1997: Impact of diazinon calamity in 1996 on the aquatic macroinvertebrates in the River Mesue, The Netherlands. Neth. J. Aquat. Ecol. 30: $327-330$

VOET, D., VOETOVÁ, J.G. 1990: Biochemie. Victoria Publishing Praha, pp. 1325 